This journal is the official publication of Bangladesh Society of Physiologists (BSP)

Web URL: www.banglajol.info/index.php/JBSP

Abstracted /indexed in Index Copernicus, Director of Open Access Journal, HINARI Index Medicus for South East Asia Region, Google Scholar, 12OR, infobse index, Open J gate, Cite factor, Scientific indexing services

pISSN-1983-1213; e-ISSN-2219-7508

Article

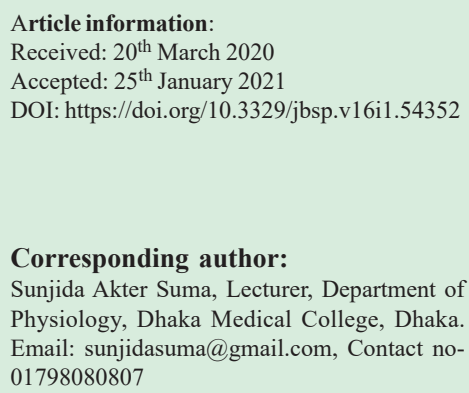

This article is open access licensed under CC BY NC SA which allows readers copy, distribute, display, and perform the work and make derivative works based on it only for noncommercial purposes.

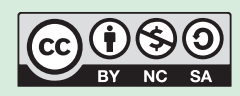

\section{Effects of hyperthyroidism on serum alanine amino transferase and alkaline phosphatase levels in liver}

\author{
Sunjida Akter Suma ${ }^{1}$, Qazi Shamima Akhter ${ }^{1}$ \\ 1. Department of Physiology, Dhaka Medical College, Dhaka.
}

\section{Abstract}

Background: Hyperthyroidism is one of the most common endocrine disorders. Thyroid hormones are essential for normal metabolic function of body cells including the liver cells. Again, metabolism of thyroid hormones takes place in liver. Therefore, hyperthyroidism may affect liver cells and causes change in hepatic enzymes level. Objective: To assess serum alanine aminotransferase (ALT) and alkaline phosphatase (ALP) levels in hyperthyroid patients. Methods: This cross sectional study was conducted in the Department of Physiology of Dhaka Medical College from July 2016 to June 2017. Total number of 50 subjects of both sexes aged from 18 to 50 years were selected. Among them, 25 hyperthyroid patients were considered as the study group (B) and 25 age matched healthy subject were considered as control group (A). Serum ALT and ALP were estimated in the Biochemistry \& Molecular Biology Department of BSMMU. For statistical analysis, Unpaired student's ' $t$ ' test and Chi Square test were done. Results: Serum ALT and ALP levels were significantly $(p<0.001)$ increased in patients suffering from hyperthyroidism. Conclusions: This study showed that detection of changes in serum hepatic enzymes in hyperthyroidism useful for prediction of developing liver disease.

Keywords: Hyperthyroid, $\mathrm{FT}_{4}$, TSH, ALT, ALP 
Introduction

$\mathbf{T}$

hyroid gland is one of the major endocrine glands of our body. It synthesizes and releases two hormones, thyroxine $\left(\mathrm{T}_{4}\right)$ and tri- iodothyronine $\left(\mathrm{T}_{3}\right)$. Thyroxine and tri- iodothyronine are required for normal growth, development and function of human body. These hormones regulate the basal metabolic rate of all cells, including hepatocytes and thereby modulate hepatic functions. Thus, any disorder in thyroid may disturb liver function ${ }^{1}$.

Hyperthyroidism caused by an overactive thyroid gland. It's a common endocrine disorder affects worldwide people. Causes of hyperthyroidism are excess iodine in diet, Graves' disease, thyroiditis, toxic nodular goiter and multinodular goiter ${ }^{2}$. Hyperthyroidism have potentially fatal systemic manifestations. Complications of hyperthyroidism are atrial fibrillation, congestive cardiac failure, osteoporosis, preeclampsia, fetal thyroid dysfunction ${ }^{3-4}$.

Hyperthyroidism act as a risk factor for future development of primary biliary cirrhosis, hepatitis, fatty infiltration, acute hepatocellular injury, hyperbilirubinemia and coagulopathy, which may progress into liver failure and hepatocellular carcinoma. So, circulating hepatic enzymes including alanine aminotransferase (ALT) and alkaline phosphatase (ALP) are found to be elevated in hyperthyroidism. ${ }^{5-7}$

ALT is a cytoplasmic enzyme, which catalyzes transfer of amino group. ALT is primarily localized to the liver. Its concentration is very high in liver and relatively low in other tissueskidney, pancreas, brain, skeletal muscle and heart tissues. Raised ALT is found in viral hepatitis, ischemic liver injury and toxin induced liver damage. ${ }^{8-10}$

ALP refers a group of phosphomonoesterases that hydrolyze phosphate esters. This enzyme ALP is found in most tissues of the human body like kidney, liver, bone, intestine and placenta.
Raised serum ALP is found in viral hepatitis, cholestasis, bone disease, metastatic liver disease and bile duct obstruction. ${ }^{11}$

Some studies have done to investigate the levels of serum ALT and ALP level in hyperthyroidism. But very few published data available in our country. Some investigators showed that thyroid hormone has effects on liver ${ }^{2,11}$. Serum ALT and ALP level were elevated in hyperthyroid subjects $^{12}$. So, this study has been designed to assess serum ALT and ALP level in hyperthyroid patients which might be helpful for prediction of future risk of developing liver disease.

\section{Method}

This cross sectional study was conducted in the Department of Physiology, Dhaka Medical College, Dhaka from July 2016 to June 2017 after approval from the ethical review committee from this institute. Total number of 50 subjects of both sexes aged from 18 to 50 years were selected. Twenty-five Newly diagnosed hyperthyroid patients were selected on the basis of clinical history, biochemical evidence (serum $\mathrm{FT}_{4}$, TSH levels) and were enrolled in study group (B) from Outpatients Department of Endocrinology, Dhaka Medical College Hospital, Institute of Nuclear Medicine and Allied Sciences, Dhaka and 25 age matched apparently healthy, no liver and acute or chronic systemic disease with normal thyroid function test were considered as control group (A). Patients who were under treatment or previously treated for hyperthyroidism, history of liver disease, history of alcohol consumption in previous 6 months were excluded. Informed written consent was taken from the participants after proper briefing about the nature, purpose and benefit of the study. Before taking blood, detailed family and medical history were taken. Anthropometric measurement of the subjects was done and blood pressure was measured. With aseptic precaution, $4 \mathrm{ml}$ of 
venous blood was collected from ante- cubital vein by a disposable plastic syringe and serum was prepared and sent to lab for estimation serum ALT and ALP by auto analyzer. All the parameters were expressed as mean \pm SD. Unpaired student ' $t$ ' test and chi- square test were performed as applicable. $P$ value $<0.05$ was accepted as level of significance. Statistical analysis was performed by using a computer based statistical program SPSS (Statistical package for social science) version 22.0.

Results

In this study, no significant differences were observed in age, sex, BMI and blood pressure between study and control group (table I). The mean $( \pm \mathrm{SD})$ serum $\mathrm{FT}_{4}$ level in the group B was increased and serum TSH level in the group B was decreased than that of group A which was statistically significant $(p<0.001)$ (table II). The mean $( \pm \mathrm{SD})$ serum ALT and ALP level in the group B was increased than that of group A which was statistically significant $(p<0.001)$ (figure 1 and figure 2).

Table I: General characteristics of the subjects in both groups $(\mathrm{N}=50)$

\begin{tabular}{lcc}
\hline & $\begin{array}{c}\text { Euthyroid } \\
(\mathrm{n}=25)\end{array}$ & $\begin{array}{c}\text { Hyperthyroid } \\
(\mathrm{n}=25)\end{array}$ \\
\hline Age (years) & $35.36 \pm 11.78$ & $30.92 \pm 8.41$ \\
Sex (\%) & & \\
$\quad$ Male & $12(48.0)$ & $10(40.0)$ \\
$\quad$ Female & $13(52.0)$ & $15(60.0)$ \\
Height $(\mathrm{cm})$ & $163.12 \pm 11.47161 .06 \pm 11.35$ \\
Weight $(\mathrm{kg})$ & $59.40 \pm 8.98$ & $56.96 \pm 10.01$ \\
BMI $\left(\mathrm{kg} / \mathrm{m}^{2}\right)$ & $22.16 \pm 2.36$ & $21.66 \pm 2.67$ \\
Systolic BP $(\mathrm{mmHg})$ & $120.2 \pm 9.3$ & $118.8 \pm 10.9$ \\
Diastolic BP $(\mathrm{mmHg})$ & $78.2 \pm 7.0$ & $79.0 \pm 7.5$ \\
\hline
\end{tabular}

Results are expressed as mean \pm SE. Statistical analysis was done by unpaired students ' $t$ ' test and Chi square test. $\mathrm{BMI}=$ Body mass index, $\mathrm{BP}=$ blood pressure. $p$ value $<0.05$ was accepted as level of significance. $\mathrm{n}=$ number of subjects in each group, $\mathrm{N}=$ total number of subjects.

Table II: Mean serum $\mathrm{FT}_{4}$, $\mathrm{TSH}$ levels of the subjects in both groups $(\mathrm{N}=50)$

\begin{tabular}{lcc}
\hline parameters & $\begin{array}{c}\text { Euthyroid A } \\
(\mathrm{n}=25)\end{array}$ & $\begin{array}{c}\text { Hyperthyroid B } \\
(\mathrm{n}=25)\end{array}$ \\
\hline $\mathrm{FT}_{4}(\mathrm{pmol} / \mathrm{L})$ & $18.22 \pm 3.69$ & $30.97 \pm 7.87^{* * *}$ \\
$\mathrm{TSH}(\mathrm{mIU} / \mathrm{L})$ & $4.61 \pm 0.28$ & $0.18 \pm 0.04^{* * *}$ \\
\hline
\end{tabular}

Results were expressed as mean \pm SE. Unpaired students ' $t$ ' test was performed to compare between groups. ${ }^{* * *} p$ value $<0.05$ was accepted as level of significance. $n=$ number of subjects in each group, $\mathrm{N}=$ total number of subjects. $\mathrm{FT}_{4}$ free thyroxine, TSH- thyroid stimulating hormone.

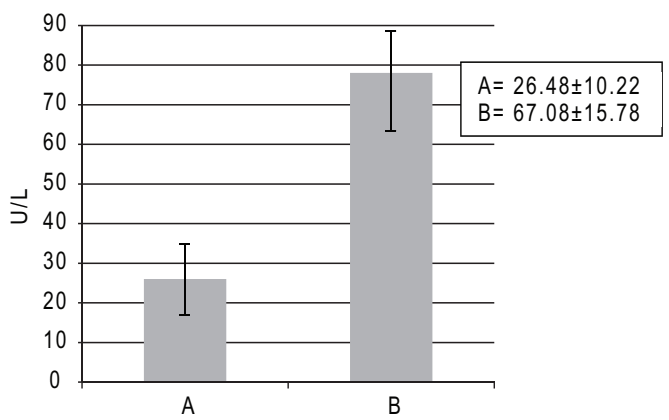

Figure 1: Mean serum alanine amino transferase (ALT) level of the subjects in both groups $(\mathrm{N}=50) . \mathrm{N}=$ total number of subjects, A- control group, B- study group (hyperthyroid)

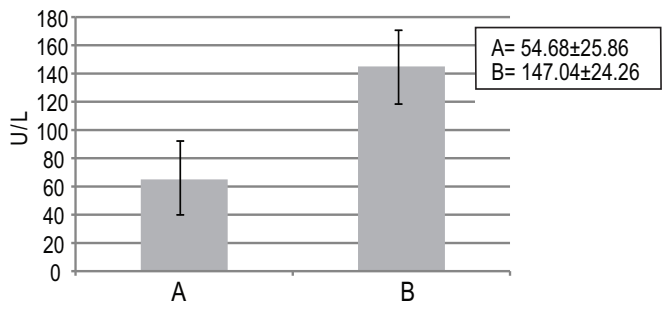

Figure 2: Mean serum alkaline phosphatase (ALP) level of the subjects in both groups $(\mathrm{N}=50) . \mathrm{N}=$ total number of subjects, $\mathrm{A}$ - control group, B- study group (hyperthyroid)

Volume 16 No. 1 June 2021: 44-48 
Discussion

In this study, the mean serum ALT and ALP level were increased in hyperthyroid patients than healthy adult subjects. In hyperthyroidism, the rate of metabolism is increased more than the average metabolic rate of the body. So, there is an increase oxygen demand without an increase in hepatic blood flow. Due to the inability of the circulation to meet increased oxygen demands results a relative hypoxia in the centri lobular region of liver. This hypoxic condition forms bulge in the cell membrane of hepatocytes, causes dilatation of cisternae of endoplasmic reticulum, rounding and swelling of mitochondria. Bulging plasma membrane bursts, then intracellular enzymes release in the blood. Thus, serum hepatic enzyme levels increase in hyper-thyroidism. ${ }^{13}$ Several studies have shown that the increase serum hepatic enzyme levels in hyperthyroidism may be caused by hepatic tissue hypoxia. This finding was in agreement with the study of many researchers of different countries ${ }^{14}$.

On the contrary, some researchers found no significant changes in serum ALT and ALP level in hyperthyroid patients. This disagreement in findings may be due to different sample size and geographical variations ${ }^{15-17}$.

\section{Conclusions}

Based on the results of the study, it can be concluded that serum ALT and ALP level were significantly increased in hyperthyroid patients than healthy controls. So, hyperthyroidism has detoriating effect on liver enzymes and assessment of serum ALT and ALP level in hyperthyroidism might be helpful for prediction of future risk of developing liver disease.

Conflict of Interest: none

Funding: self-finance

Acknowledgement

The authors acknowledge the Outpatients Department of Endocrinology, Dhaka Medical

Volume 16 No. 1 June 2021: 44-48
College Hospital, Institute of Nuclear Medicine and Allied Sciences, Dhaka, the Department of Biochemistry \& Molecular Biology of Bangabandhu Sheikh Mujib Medical University (BSMMU) for their kind cooperation.

\section{References}

1. Mansorian AR. Liver functional behavior during thyrotoxicosis. Pak J Biol Sci. 2013;13(8):665-678.

2. Pandey R, Jaiswal S, Sah JP, Bastola K, Dulal S. Assessment of serum enzymes level in patients with thyroid alteration attending manipal teaching hospital, Pokhara. J Life Sci. 2013; 3(1):1-9.

3. Aryal M, Gyawali P, Rajbhandari N, Aryal P, Pandeya DR. A prevalence of thyroid dysfunction in kathmandu university hospital, Nepal. Biomed Res. 2010; 21(4): 411-415.

4. Berber E. Causes of hypothyroidism [Internet]. New Jersey: Vertical Health; [2016 Jun 23; cited 2017 Jan 05]. Available.from:https://www.endocrineweb.com/ conditions/hypothyroidism/causes-hypothyroidism/

5. Targher G, Montagnana M, Salvagno G, Moghetti P, Zoppini G, Muggeo M Lippit G. Association between serum $\mathrm{TSH}$, free $\mathrm{T}_{4}$ and serum liver enzyme activities in a large cohort of unselected outpatients. Clin Endocrinol. 2008; 68(3):481-484.

6. Singh P, Kaushik GG, Singh P. Assessment of serum liver enzymes levels in hypothyroid and hyperthyroid subjects in Indian population. Int J Sci Res. 2015; 4(4):14-16.

7. Khemichian S, Fong TL. Hepatic dysfunction in hyperthyroidism. Gastroentrol Hepatol. 2011; 7(5): 337-339.

8. Adek M, Shivapuri JN. Enzymatic and non-enzymatic liver function test: a review. Res J Pharm Biol Chem Sci. 2010; 1(4): 593-605.

9. Kakadiya J. Liver function test - a review. Pharmacol online.2009;2(1): 271-282.

10. Hall P, Cash J. What is the real function of the liver 'function' test.Ulster Med J. 2012; 81(1): 30-36.

11. Gowda S, Desai PB, Hull VV, Math AAK, Vernekar SN, Kulkarni SS. 2009. A review of laboratory liver function tests. Pan Afr Med J. 3(17):1-10.

12. Madani SH, Far ZR, Jalilian N, Zare ME, Zadeh FS. 2014. Evaluate the liver function in hyperthyroidism patients. J Paramed Sci. 2014; 5(2):75-78. 
13. Malik R, Hodgson $\mathrm{H}$. The relationship between the thyroid gland and the liver. Q J Med. 2002; 95(9): 559-569.

14. Khan TM, Malik S, Diju IU. Correlation between plasma thyroid hormones and liver enzymes level in thyrotoxic cases and controls in hazara division. J Ayub Med Coll Abbottabad 2010; 22(2): 176-179.

15. Ibrahim MO, Ahmed SA, Idris OF. Assessment of liver enzymes levels among sudanese hyperthyroidism patients. Br J Med Health Res. 2016; 3(3): 2394-2967.

16. Najeeb MM, Saleem M, Mohammad AAW, Jabir MS. Serum enzyme activities in human thyroid diseases. Iraqi Postgrad Med J. 2011; 10(4): 549-554

17. Ajala MO, Ogunro PS, Fasanmade OA. Relationship between liver function tests and thyroid hormones in thyroid disorders. Niger Postgrad Med J. 2013; 20(3): 188-192. 